\title{
Pembentukan Karakater Siswa Kelas III SDN 054871 KW. Begumit Melalui Fabel Pendidikan Kewarganegaraan
}

\begin{abstract}
Penulis:
Ficha Aulia Nanda ${ }^{1}$

Intan Maulina ${ }^{2}$

Afiliasi:

Universitas Efarina ${ }^{1,2}$

Korespondensi

fichampd@gmail.com

Histori Naskah:

Dikirim: 28-06-2021

Accepted: 29-06-2021

Published: 01-07-2021

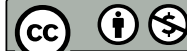

BY NC

This is an Creative Commons

License This work is licensed

under a Creative Commons

Attribution-NonCommercial 4.0

International License

Abstrak :

Pendidikan nasional berfungsi sebagai pemelihara nilai-nilai di dalam masyarakat agar terus dapat dilestarikan. Pendidikan karakter merupakan filter bagi hal negatif dalam globalisasi. Untuk menanamkan nlai-nilai pendidikan karakter, tentu tidak cukup hanya sekadar diberikan hafalan atau nilai ujian yang memenuhi standar kelulusan, namun secara keseluruhan haruslah terintegrasi antara kognitif, afektif dan psikomotorik. Dalam penelitian ini, peneliti mengkaji peningkatan karakter siswa kelas 3 SDN 054872 KW.Begumit melalui fabel Pendidikan Kewarganegaraan . Fabel merupakan cerita binatang yang diajarkan di SD kelas 3. Fabel berisi berbagai nilai yang dapat diajarkan kepada siswa. Banyak nilai pembelajaran yang dapat dieksplorasi dalam fabel yang selanjutnya dapat digunakan sebagai alternatif dalam mengedukasi siswa. Tujuan dari penelitian ini yaitu untuk menunjukkan apa saja nilai pendidikan karakter yang dapat diambil dalam fable dan mendeskripsikan bagaimana pembentukan karakter siswa kelas 3 SDN 054871 KW. Begumit melalui Pendidikan kewarganegaraan fabel. Jenis penelitian yang dilakukan dalam penelitian ini yaitu penelitian kualitatif. Hasil dari penelitian ini menunjukkan bahwa nilai karakter di dalam fabel yang dapat menjadi suri tauldan untuk siswa Sekolah Dasar Negeri 091320 diantaranya: sikap jujur, sikap tanggung jawab juga sikap rasa ingin menolong dan pembentukkan karakter siswa SDN $054871 \mathrm{KW}$. Begumit melalui fabel pendidikan kewarganegaraan dilakukan dengan pendekatan buku-buku, komunikasi yang baik, serta implementasi yaitu dengan mengajak siswa berpartisipasi untuk tampil dan guru mengajak siswa untuk mengaplikasikan apa yang mereka dapat dari cerita-cerita fabel yang telah mereka pelajari bersama.
\end{abstract}

Kata kunci: Karakter, Pendidikan Kewarganegaraans, Fabel, Pendidikan.

\section{PENDAHULUAN}

Pendidikan merupakan sebuah proses penyempurnaan diri yang sudah dilakukan jauh sejak sejarah manusia dimulai. Perbaikan demi perbaikan diri terus berlangsung hingga kini. Semua ini karena manusia pada dasarnya memiliki keterbatasan, maka untuk dapat mengembangkan diri dan terus memperbaiki kekurangan dan keterbatasan manusia pun berproses dengan pendidikan.

Pada tahun 2020 hampir di seluruh belahan di dunia terkena dampak dari adanya virus baru yang dikenal dengan virus corona/covid19. Virus yang pertama ditemukan di sebuah kota di Tiongkok, tepatnya di kota Wuhan, di provinsi Huabei. Virus yang gejalanya hampir mirip dengan flu ini, menyebar begitu cepat dan telah menewaskan hampir 100 orang perhari dan berdampak pada setiap lini kehidupan, salah satunya pendidikan. Maka semua proses beajar mengajar pun ikut menyesuaikan diri dengan protokol kesehatan yang berlaku.

Sisdiknas dalam Undang Undang No. 20 taun 2003, pasal 3 menjelaskan fungsi dari pendidikan yaitu mengembangkan kemampuan dan membentuk watak serta peradaban bangsa yang bermartabat dalam rangka mencerdaskan kehidupan bangsa, bertujuan untuk berkembangnya potensi peserta didik agar menjadi manusia yang beriman dan bertakwa kepada Tuhan Yang Maha 
Esa, berakhlak mulia, sehat, berilmu, cakap, kreatif, dan menjadi warga negara yang demokratis dan bertanggung jawab.

Pendiidkan nasional juga berfungsi sebagai pemelihara nilai-nilai di dalam masyarakat agar terus dapat dilestarikan, mengembangkan masyarakat untuk tumbuh lebih baik dengan sumber daya manusia yang memadai, yang berbudi pekerti dan menjadi manusia Indonesia seutuhnya. Fungsi ini tidak akan terwujud jika hanya pemerintah saja yang turun tangan untuk mengatasinya, maka tugas ini membutuhkan bantuan dari semua pihak dan seluruh lapisan masyarakat.

Kurikulum tingkat satuan pendidikan (KTSP) menjadi acuan bagi standar pendidikan nasional yang berfungsi untuk mengembangkan pembelajaran, penilaian dan tujuan dari pendidikan di Sekolah Dasar (SD). Pengembangan karakter ini juga harus masuk ke dalam materi pembelajaran serta diaplikasikan dalam kehidupan sehari-hari.

Thomas Lickona (Muchlas Samani, 2012: 44) menjelaskan bahwa pendidikan karakter bertujuan untuk menolong seseorang untuk memahami, perduli dan bertindak etis. Muchlas Samani (2012: 45) juga menyatakan bahwa pendidikan karakter merupakan sebuah panduan untuk peserta didik agar dapat menajdi manusia seutuhnya yang memiliki karakter dalam dimensi hati, pikir, raga, serta rasa dan karsa.

Sebagai bagian dari aspek kepribadian, karakter juga merupakan cerminan kepribadian seseorang; mentalitas, sikap, dan perilaku. Karakter memiliki kaitan secara fisik juga psikis sesorang. Karakter bersifat kontekstual dan kultural.

Pendidikan karakter merupakan filter bagi hal negatif dalam globalisasi. Pendidikan karakter merupakan pendidikan yang mendukung perkembangan sosial, emosional, dan etis siswa (Barnawai \& M. Arifin, 2012: 5). Pendidikan karakter bermakna juga sebagai perilaku, moral atau pendidikan akhlak, yang bertujuan untuk membentuk pribadi anak, agar menjadi pribadi yang baik, jika di masyarakat menjadi warga yang baik, dan jika dalam kehidupan bernegara menjadi warga negara yang baik (T. Ramli, 2003: 34).

Untuk menanamkan nlai-nilai pendidikan karakter, tentu tidak cukup hanya sekadar diberikan hafalan atau nilai ujian yang memenuhi standar kelulusan, namun secara keseluruhan haruslah terintegrasi antara kognitif, afektif dan psikomotorik. Salah satunya bisa ditempuh dengan menyajikan langsung sebuah peristiwa-peristiwa nyata yang dirangkum dalam satuan mata pelajaran, seperti perangkat media massa, Tv, radio, internet, surat kabar, karya sastra dan lainlain yang dapat membantu dalam proses pembelajaran.

Pada masa kini banyak dari guru yang menjadikan dongeng sebagai salah satu media guru menanamkan nilai pendidikan karakter, disamping menggunakan bahasa yang mudah dipahami juga meniratkan pesan-pesan moral yang dapat diambil sisi positifnya, yang kemudian dapat diterapkan dalam kehidupan sehari-hari.

Cerita rakyat merupakan warisan leluhur turun temurun yang menggambarkan budaya, adatistiadat, suku serta agama tiap daerah di Indonesia. Wilayah Indonesia dari Sabang sampai Marauke memiliki cerita rakyat Melalui cerita rakyat, anak-anak dapat mengenal kepribadian bangsa Indonesia serta secara tidak langsung menanamkan karakter yang sesuai dengan prinsip Pancasila (Melasarianti, 2015: 1).

Dongeng adalah jenis cerita yang dicirikan oleh karakter non-manusia, misalnya hewan, di dalamnya. Pemahaman fabel ini, seringkali, tidak setara dengan pengetahuan di luar cerita, yang merupakan nilai moral. Berdasarkan hasil penelitian terdahulu pada siswa Sekolah Dasar dan Sekolah Menengah Pertama, diperoleh informasi bahwa mereka senang membaca teks dongeng, namun, banyak dari mereka menganggap dongeng sebagai sekadar membaca teks dengan karakter 
fauna dan tidak benar-benar mengetahui dan menyadari bahwa cerita itu mengandung pelajaran moral (Abrar, 2016: 48).

Produk sastra yang dipersiapkan untuk anak-anak sangat penting dalam belajar dan mengajar bahasa. Dongeng dongeng, yang berakar dalam sastra Barat atau Timur, adalah salah satu karya dongeng yang mungkin menarik perhatian anak-anak saat ini. Fakta bahwa dongeng dimaksudkan untuk mengajarkan pelajaran memungkinkan mereka untuk digunakan dalam pendidikan (Jackson, \& Heath, 2017: 541)

Dalam penelitian ini, peneliti mengkaji peningkatan karakter siswa kelas 3 SDN 01320 Raya Tongah melalui fabel pendidikan kewarganegaraan. Fabel merupakan cerita binatang yang diajarkan di SD kelas 3. Fabel berisi berbagai nilai yang dapat diajarkan kepada siswa. Banyak nilai pembelajaran yang dapat dieksplorasi dalam fabel yang selanjutnya dapat digunakan sebagai alternatif dalam mengedukasi siswa. Fabel dapat membentuk kepribadian anak dan orang dewasa karena karakter yang diperankan oleh binatang, tanaman, atau benda lainnya dapat dibaratkan sebagai sifat manusia (Yono, 2014: 103).

\section{KAJIAN PUSTAKA \\ Pembentukan Karakter}

Secara etimologis, Kata karakter berasal dari bahasa Yunani yaitu charassein, yang maknanya to engrave (Ryan and Bohlin, 1999:5 dalam Marzuki, 2015:19). Marzuki (2015:20) juga mengutip pendapat dari Echols \& Shadily (1995:214) dan menerjemahkan kata to engrave menjadi mengukir, melukis, memahatkan, atau menggoreskan.

Di dalam Kamus Besar Bahasa Indonesia, karakter diartikan sebagai sifat-sifat kejiwaan, akhlak atau budi pekerti, tabiat, dan watak yang membedakan seseorang dari yang lain. (Depdiknas, 2008:623 dalam Saptono, 2011:17).

Secara terminologis, karakter diartikan oleh Kemendiknas (2010) yang dikutip oleh Agus Wibowo (2013:13) berarti sebagai watak, tabiat, akhlak atau kepribadian seseorang yang terbentuk dari hasil internalisasi berbagai kebajikan, yang diyakini dan digunakan sebagai landasan untuk cara pandang, berpikir, bersikap dan bertindak.

Maksudin (2013:3) menjelaskan karakter sebagai ciri khas setiap individu yang berhubungan dengan jati dirinya yang merupakan kualitas batiniah, baik cara berpikir dan berperilaku dalam hidup dan bekerja sama, baik dalam lingkup keluarga, masyarakat, bangsa dan negara.

Pengertian karakter sebagai kepemilikan akan hal-hal yang baik, objektivitas yang baik atas kualitas manusia. (Thomas Lickona, 2013:15).

Karakter adalah diri kita apa adanya, dasar dari kepribadian dan sifat seseorang (Tim Preschool Online, 2015:2). Zainal Aqib (2011:30) mendefiniskan karakter sebagai aktualisasi potensi dari dalam dan internalisasi nilai-nilai moral dari luar menjadi bagian dari kepribadiannya. Abdullah Munir (2010:3) berpendapat bahwa karakter adalah sebuah pola, baik itu pikiran, sikap maupun tindakan yang melekat pada diri seseorang dengan sangat kuat dan sulit dihilangkan.

Dari uraian di atas dapat ditarik kesimpulan bahwa karakter adalah cara berpikir dan berperilaku yang khas tiap individu yang terbentuk dari hasil internalisasi berbagai kebajikan, merupakan ciri khas dan melekat pada diri seseorang dengan sangat kuat yang membedakan seseorang dengan yang lainnya, untuk hidup dan bekerja sama, baik dalam lingkup keluarga, masyarakat, bangsa dan negara.

Pendidian karakter sebagai upaya mendorong peserta didik tumbuh dan berkembang dengan kompetensi berpikir dan berpegang teguh pada prinsip-prinsip moral dalam hidupnya serta mempunyai keberanian melakukan yang benar, meskipun dihadapkan pada berbagai tantangan. 
Untuk itu penekanan pendidikan karakter tidak terbatas pada transfer pengetahuan mengenai nilainilai yang baik, namun lebih dari itu menjangkau pada bagaimana menjadikan nilai-nilai tersebut tertanam dan menyatu dalam totalitas pikiran-tindakan.

Pendidikan karakter telah menjadi polemik di berbagai Negara. Pandangan pro dan kontra mewarnai diskursus pendidikan karakter sejak lama. Sejatinya, pendidikan karakter merupakan bagian esensial yang menjadi tugas sekolah. Tetapi selama ini kurang perhatian. Akibat minimnya perhatian terhadap pendidikan karakter dalam ranah persekolahan, sebagaimana dikemukakan Lickona telah menyebabkan berkembangnya berbagai penyakit sosial ditengah masyarakat. Seyogianya, sekolah tidak hanya berkewajiban meningkatkan pencapaiaan akademis, tetapi juga bertangung jawab dalam membentuk karakter peserta didik. Capaian akademis dan pembentukan karakter yang baik merupakan dua isi integral yang harus mendapat perhatian sekolah. Namun, tuntutan ekonomi dan politik pendidikan menyebebkan penetapan pada pencapaian akademis mengalahkan idealitas peran sekolah dalam membentuk karakter.

Menurut Sjarkawi, 2006: 14 pendidikan karakter diartikan sebagai usaha kita secara sengaja dari seluruh dimensi kehidupan sekolah untuk membantu mengembangkan karakter dengan optimal. Hal ini berarti bahwa untuk mendukung perkembangan karakter peserta didik harus melibatkan seluruh komponen disekolah baik dari aspek isi kurikulum, proses pembelajaran, kualitas hubungan, penanganan mata pelajaran, pelaksanaan aktivitas ko-kurikuler, serta etos seluruh lingkungan sekolah.

Raharjo dalam jurnalnya yang berjudul pendidikan karakter sebagai upaya menciptakan akhlak mulia 2010, memaknai pendidikan karakter sebagai suatu proses pendidikan secara holistis yang menghubungkan dimensi moral dengan ranah sosial dalam kehidupan peserta didik sebagai fondasi bagi terbentuknya generasi yang berkualitas yang mampu hidup mandiri dan memiliki suatu kebenaran yang dapat dipertanggungjawabkan.

Upaya ini juga memberi jalan untuk menghargai persepsi dan nilai- nilai pribadi yang ditampilkan disekolah. Fokus pendidikan karakter adalah pada tujuan-tujuan etika, tetapi praktiknya meliputi penguatan kacakapan-kecakapan yang penting yang mencangkup perkembangan sosial siswa.

Nilai adalah keyakinan yang membuat seseorang bertindak atas dasar pilihannya. Hal ini dikemukakan oleh Gordon Allport (Rahmat Mulyana, 2004: 9) bahwa nilai adalah keyakinan, hasrat, motif, sikap, keinginan, dan kebutuhan. Oleh karena itu, keputusan benar-salah, baikburuk, dan indah-tak indah merupakan hasil dari serentetan proses psikologis yang kemudian mengarahkan individu pada tindakan dan perbuatan yang sesuai dengan nilai pilihannya.

Nilai karakter terwujud dalam kejujuran, tanggung jawab, kepedulian, dan semua perbuatan baik. Menurut Lickona (1991: 38) membedakan nilai ke dalam dua kategori.

Nilai ada dua macam, yaitu nilai moral dan nilai nonmoral. Nilai moral adalah rasa keharusan untuk dilakukan, dalam hal ini kejujuran, tanggung jawab, kesungguhan dalam mengembankan kewajiban, menepati janji, membayar tagihan, peduli pada anak-anak, dan adil dalam membuat kesepakatan dengan pihak lain. Nilai moral mengajarkan apa yang seharusnya dikerjakan, meskipun kadang kita tidak suka melakukannya. Sedangkan nilai nonmoral adalah nilai yang tidak menuntut keharusan untuk dilakukan, misalnya seseorang suka mendengarkan music klasik, atau suka membaca novel yang bagus tetapi tidak ada keharusan melakukan itu.

Berdasarkan beberapa pengertian di atas, bisa disimpulkan bahwa nilai merupakan esensi yang melekat pada sesuatu yang sangat berarti bagi kehidupan manusia. Selain itu nilai merupakan keyakinan dalam menentukan pilihan agar para siswa mengenal dan menerima nilai sebagai milik mereka dan bertanggung jawab atas keputusan yang diambilnya melalui tahapan 
mengenal pilihan, menilai pilihan, menentukan pilihan, dan pendirian, serta menerapkan nilai sesuai dengan keyakinan sendiri. Pendidikan nilai membantu siswa agar meningkat dalam afektifnya, yakni dari tingkat yang paling bawah (menerima pernyataan tentang nilai karakter) melalui tingkat merespon, kemudian menghargainya, memiliki komitmen terhadap nilai tersebut dan akhirnya menginternalisasi sistem nilai-nilai sebagai tingkat tertinggi dalam perkembangan afektif.

\section{Pendidikan Kewarganegaraan}

Pendidikan Kewarganegaraan Pendidikan Kewarganegaraan diambil dari istilah Civic Education, dan oleh sebagian pakar diterjemahkan ke dalam bahasa Indonesia menjadi Pendidikan Kewargaan dan Pendidikan Kewarganegaraan.Istilah Pendidikan Kewargaan diwakili oleh Azyumardi Azra dan Tim ICCE (Indonesian Center for Civic Education), sedangkan istilah Pendidikan Kewarganegaraan diwakili oleh Zamroni, Muhammad Numan Soemantri, Udin. S. Winataputra, dan Tim CICED (Center Indonesian for Civic Education).

Rosyada, dkk (2000:7) memberikan pendapat bahwa, "Pendidikan Kewarganegaraan itu sama dengan Pendidikan Demokrasi yang bertujuan untuk mempersiapkan warga masyarakat untuk dapat berfikir kritis dan bertindak demokratis, melalui aktivitas menanamkan kesadaran kepada generasi baru bahwa kesadaran demokrasi adalah bentuk kehidupan Budi Juliardi, Implementasi Pendidikan Karakter Melalui Pendidikan Kewarganegaraan 121 masyarakat yang paling menjamin hak-hak warga masyarakat". Lebih lanjut, Rosyada, dkk (2000:7) memberi pengertian mengenai Pendidikan Kewarganegaraan yaitu; "Pendidikan Kewarganegaraan adalah suatu proses yang dilakukan oleh lembaga pendidikan di mana seseorang mempelajari orientasi, sikap dan prilaku politik sehingga yang bersangkutan memiliki pengetahuan politik serta kemampuan mengambil keputusan politik secara rasional dan menguntungkan bagi dirinya juga bagi masyarakat dan bangsa". Pada hakikatnya, pengajaran PKn berbeda dengan pengajaran pendidikan lain, karena pengajaran PKn ini sulit untuk mendapatkan ketepatan jika dibanding dengan pengajaran Ilmu Pengetahuan Alam (IPA). Dalam buku terbitan Ditjen. Dikdasmen, Depdiknas(2003:4), sebagaimana lazimnya suatu bidang studi yang diajarkan di sekolah, PKn memiliki karakteristik yang mencakup 3 (tiga) dimensi, yaitu:

1) dimensi pengetahuan kewarganegaraan (knowledge), yang mencakup bidang politik, hukum dan moral;

2) dimensi keterampilan kewarganegaraan (Skills), meliputi keterampilan partisipasi dalam kehidupan berbangsa dan bernegara; dan

3) dimensi nilai-nilai kewarganegaraan (values), mencakup antara lain percaya diri, penguasaan atas nilai religius, norma dan moral luhur.

Karakteristik tersebut di atas dimaksudkan agar sejalan dengan ide pokok pelajaran PKn yang ingin membentuk warga negara yang ideal, yaitu warga negara yang beriman dan bertaqwa terhadap Tuhan Yang Maha Esa, berpengetahuan, berketerampilan, dan memiliki nilai-nilai yang sesuai dengan prinsip-prinsip Kewarganegaraan.Sikap inilah yang disebut dengan sikap yang berkarakter. Pendidikan Karakter Pendidikan karakter merupakan bentuk kegiatan manusia yang di dalamnya terdapat suatu tindakan yang mendidik diperuntukkan bagi generasi selanjutnya (Kusuma, 2007:3).Tujuan pendidikan karakter adalah untuk membentuk penyempurnaan diri individu secara terus-menerus dan melatih kemampuan diri demi menuju kearah hidup yang lebih baik. Wynne (dikutip oleh Zuchdi, 2009), menyatakan bahwa istilah karakter diambil dari bahasa yunani yang berarti ,to mark ${ }^{\text {ee }}$ (menandai).Istilah ini lebih difokuskan pada bagaimana upaya 
pengaplikasian nilai kebaikan dalam betuk tindakan atau tingkah laku. Lebih lanjut, Wynne mengatakan bahwa ada dua pengertian tentang karakter.Kesatu, karakter menunjukkan bagaimana seseorang bertingkah laku.

Dapat diambil suatu kesimpulan bahwa yang dimaksud dengan Pendidikan Kewarganegaraan itu pada hakikatnya adalah program pendidikan yang memuat bahasan tentang masalah kebangsaan, kewarganegaraan dalam hubungannya dengan negara, demokrasi, Hak Asasi Manusia, dan masyarakat madani yang dalam implementasinya menerapkan prinsip-prinsip pendidikan demokratis dan humanis.

\section{Fabel}

Fabel menurut Fang (2011: 4-5) adalah salah satu bentuk sastra rakyat yang sangat populer. Tiap-tiap bangsa di dunia ini mempunyai cerita binatang. Misalnya saja bangsa Melayu yang memiliki cerita hampir sama, yaitu cerita kancil. Tidak hanya terdapat di tanah Melayu, tetapi juga di Jawa, India, dan Eropa. Hanya saja yang membedakan adalah tokoh binatangnya. Cerita binatang (fables, fabel) adalah salah satu bentuk cerita tradisional yang menampilkan binatang sebagai tokoh cerita. Binatang-binatang tersebut dapat berpikir dan berinteraksi layaknya komunitas manusia, lengkap dengan permasalahan hidup layaknya manusia. Mereka dapat berpikir, berlogika, berperasaan, berbicara, bersikap, bertingkah laku, dan lain-lain sebagaimana manusia dengan bahasa manusia. Cerita binatang seolah-olah tidak berbeda halnya dengan cerita yang lain, artinya cerita dengan tokoh manusia juga menampilkan binatang sebagai tokoh lainnya (Nurgiyantoro, 2005: 190).

Diuraikan dalam bukunya Nurgiyantoro (2005: 191) cerita fabel berkaitan dengan dunia binatang dan tidak secara langsung menunjuk manusia, dan karenanya bersifat imperasional, pesan moral atau kritik yang ingin disampaikan menjadi lebih bersifat tidak langsung. Hal itu menyebabkan pembaca menjadi lebih senang dan menikmati, dan kalaupun termasuk yang terkena kritik, menjadi tidak terasa serta-merta karena baik yang memberikan kritik dan pesan maupun 7 yang dituju adalah sama-sama binatang. Hal itu pula yang menyebabkan cerita binatang menjadi amat populer, disenangi anak-anak dan orang dewasa, dan bersifat universal. Jadi fabel merupakan cerita binatang yang menampilkan binatanag sebagai tokoh dalam cerita. Binatang-binatang tersebut dapat bertingkah laku layaknya manusia lengkap dengan permasalahan yang dihadapi layaknya manusia. Mereka dapat berpikir, berbicara, memiliki perasaan, dan lain-lain layaknya manusia. Fabel bertujuan untuk memberikan pesan moral yang ingin disampaikan penulis kepada pembaca.

Fabel atau cerita binatang sudah ada sejak zaman dahulu, tidak hanya tersebar di daerah-daerah di Indonesia, namun juga tersebar di negara-negara lain. Di India terkenal dengan fabel yang berjudul Jataka, Pacatantra, dan Sukasaptati. Di Indonesia tekenal dengan cerita kancil. Cerita kancil juga terdapat di negaranegara lain seperti Eropa, Tiongkok, Arab, dan masih banyak lagi negara lain. Secara garis besar, fabel yang diceritakan di negara lain kurang lebih sama, yang membedakan hanyalah tokoh utamanya. Dalam sastra Melayu dan Jawa, binatang kancil disebut degan Pelanduk. Dalam sastra Sunda binatang yang digunakan adalah Kera. Di daerah Toraja di Sulawesi binatang yang memegang peranan penting adalah Nggasi atau Kerahantu. Di Campa, Kamboja, dan Annam, binatangnya adalah Arnab (Fang, 2011: 5).

\section{Sastra Anak}


Sastra anak merupakan sebuah karya sastra yang menawarkan kesenangan dan pemahaman. Kurniawan (2013:23) mengemukakan bahwa sastra anak merupakan sebuah karya sastra yang ceritanya berkolerasi dengan dunia anak-anak dan bahasa yang digunakan sesuai dengan perkembangan intelektual, dan emosional anak.

Lukens (2003:30) mengemukan bahwa secara garis besar genre sastra anak terbagi menjadi lima macam, yaitu fiksi, non fiksi, puisi, sastra tradisional, komik. Fiksi merupakan bentuk prosa. Jika dilihat dari ceritanya menampilkan cerita hayalan atau cerita imajinatif. Cerita fiksi anak yang berkembang di luar negeri maupun di Indonesia sangatlah beragam. Hal ini terbukti dengan banyaknya jenis fiksi dalam fiksi anak. Fiksi fantasi misalnya, fiksi fantasi $50 \%$ lebih banyak terdapat pada negara maju khususnya di negara benua Eropa. Contoh fiksi fantasi seperti Harry Potter, badman, superman, dll. Fiksi ilmiah misalnya, fiksi ilmiah banyak berkembang di negara negara asia seperti Jepang, Korea, Taiwan dll. Berkembangnya beberapa fiksi anak di dunia akan mempengaruhi perkembangan fiksi anak di Indonesia.

\section{METODE PENELITIAN}

Penelitian ini dilakukan kepada SD kelas III SDN $054871 \mathrm{Kw}$.begumit ini menggunakan penelitian deskriptif kualitatif. Peneliti menggunakan penelitian kualitatif karena dalam proses penelitian ini banyak dilakukan di lapangan dan pengamatan langsung. Penelitian dilakukan di SDN 054871 Kw. Begumit yang beralamat di dusun II Desa Suka Makmur Kw. Begumit Kabupaten Langkat. Analisis dalam penelitian ini menggunakan teknik analisis data dengan menggunakan peneliltian Miles dan Huberman dalam Gunawan (2015: 210) yaitu reduksi data, penyajian data dan penerikan kesimpulan atau verifikasi data.

Observasi digunakan untuk memperoleh data situasi sosial yang terdiri dari tempat (Place), pelaku (Actor), dan kegiatan (Activity). Peneliti menggunakan pedoman observasi pelaksanaan pendidikan karakter di sekolah. Analisis dalam penelitian ini menggunakan teknik analisis data dengan menggunakan peneliltian Miles dan Huberman dalam Gunawan (2015: 210) yaitu reduksi data, penyajian data dan penerikan kesimpulan atau verifikasi data

\section{HASIL DAN PEMBAHASAN \\ Fakta Temuan Lapangan \\ Gambaran Umum SDN 054871 KW. Begumit}

Sekolah SD 054871 berada di daerah KW. Begumit dan memiliki jumlah siswa yang tergolong sedikit, untuk kelas III hanya memiliki 8 orang siswa. Sekolah dimulai pukul 7.15 WIB sama seperti sekolah SD pada umumnya hingga selesai pada pukul $12.50 \mathrm{WIB}$, namun guru biasa akan pulang setelah pukul 14.50 WIB setelah melakukan kegiatan lain di sekolah seperti memeriksa tugas yang dikumpulkan atau membuat bahan ajar utuk esok harinya juga mengadakan rapat jika diperlukan.

Para guru tergolong rajin datang untuk mengajar dapat dilihat dari data daftar hadir guru. Guru tetap yang ditempatkan dari pemerintah ada sekitar 7 orang, 6 guru kelas dan 1 orang kepala sekolah juga ditambah beberapa orang guru swasta yang diperbantukan. Siswa juga rajin datang biar pun untuk keseluruhan siswa tidak banyak tapi daftar hadir siswa menunjukkan bahwa hampir setiap harinya siswa datang ke sekolah dan mengikuti pelajaran dengan baik.

Akses ke sekolah dapat dijangkau dengan baik, dapat ditempuh dengan berbagai kendaraan atau pun dengan berjalan kaki, karena beberapa siswa yang memang bertempat tinggal tak jauh dari lokasi sekolah biasa pergi ke sekolah dengan berjalan kaki, kecuali jika hujan lebat turun, maka biasanya siswa akan terlambat atau pun tidak datang ke sekolah, tapi itu sangat jarang terjadi. 
Tabel 4.2.1. Data Informan

\begin{tabular}{|c|c|}
\hline Nama & SUNDARI \\
\hline NIP & 19670707 200001 2 001 \\
\hline Tempat, Tanggal Lahir & Perdagangan, 07 Juli 1967 \\
\hline Usia & 54 Tahun \\
\hline Jenis kelamin & Perempuan \\
\hline Jabatan & Wali Kelas III \\
\hline
\end{tabular}

Sumber: Hasil Penelitian

Informan bernama Sundari menjabat sebagai guru Pendidikan Kewarganegaraan /wali kelas III Sekolah Dasar Negeri 054871 KW.begumit. Ibu Sundari adalah pengajar yang merupakan bagian dari Pegawai Negeri Sipil (PNS) yang mendapatkan penempatan di sekolah tersebut.

Ibu Sundari dalam mengajar lebih mengutamakan untuk membangun karakter siswa seperti isu yang marak digaungkan pemerintah belakangan ini. Bagi ibu Sundari moral siswa jauh lebih baik dibanding nilai angka-angka yang mereka dapatkan di rapor, namun memang lebih baik jika siswa menunjukkan moral dan nilai yang juga baik. Itulah sebabnya beliau sangat antusias untuk mendidik para siswanya.

Adapun jadwal penelitian yang dilakukan kepada Ibu Sundari dapat dilihat pada tabel ini:

Tabel 4.2.2. Judul Tabel belum ada

\begin{tabular}{|c|l|c|l|}
\hline No & \multicolumn{1}{|c|}{ Hari dan Tanggal } & Waktu & \multicolumn{1}{|c|}{ Keterangan } \\
\hline 1 & Senin, 05 Oktober 2020 & 08.00 WIB & Observasi \\
\hline 2 & Sabtu, 10 Oktober 2020 & 13.00 WIB & $\begin{array}{l}\text { Observasi dan } \\
\text { Wawancara }\end{array}$ \\
\hline 3 & Selasa, 13 Oktober 2020 & 10.00 WIB & $\begin{array}{l}\text { Observasi dan } \\
\text { Dokumentasi }\end{array}$ \\
\hline
\end{tabular}

Sumber: Hasil Penelitian

\section{Pembentukan Karater Siswa Kelas 3 SDN 054871 KW. Begumit Melalui Fabel pendidikan kewarganegaraan}

Kegiatan penelitian ini dilakukan secara daring dan luring di SDN 054871 KW. Begumit,. Penelitian dilaksanakan sejak 5 Oktober 2020. Penelitian ini dilakukan dengan cara melakukan wawancara terhadap guru wali kelas SDN $054871 \mathrm{KW}$. Begumit, wawancara ini dilakukan sebagai bentuk tambahan informasi untuk menunjang hasil dari penelitian.

Wawancara dilakukan untuk mendapatkan hasil yang kredibel karena dilakukan secara langsung terhadap pelaku kegiatan pembelajaran selaku guru kelas yang mengajarkan materi di sekolah. Daftar pertanyaan berisikan sepuluh pertanyaan yang diajukan dan dijawab secara langsung oleh guru kelas. Berdasarkan pengamatan guru kelas yang menjadi sumber penelitian sangat kooperatif dan tidak mempersulit peneliti dalam melakukan penelitiannya.

Pendidikan nilai karakter di sekolah tidak masuk ke dalam kurikulum wajib, tetapi pendidikan yang bisa diintegrasikan dalam semua mata pelajaran. Pendidikan sekolah merupakan salah satu perantara untuk kemudian diaplikasikan dikehidupan sehari-hari.

Pendidikan karakter merupakan upaya yang dilakukan para personel sekolah untuk membantu anak-anak agar memahami dan mengimplementasikan apa dan bagaimana nilai karakter. Wangid (2010:174-175) menjelaskan, secara khusus tujuan pendidikan karakter atau 
moral adalah membantu siswa agar secara moral lebih bertenggung jawab menjadi warga negara yang lebih disiplin.

Pendidikan karakter juga berupaya mendorong peserta didik tumbuh dan berkembang dengan kompentensi berpikir dan berpegang teguh pada prinsip-prinsip moral dalam hidupnya serta mempunyai keberanian melakukan yang benar, meskipun dihadapkan pada berbagai tantangan. Untuk itu penekanan pendidikan karakter tidak terbatas pada transfer pengetahuan mengenai nilai-nilai yang baik, namun lebih dari itu menjangkau pada bagaimana nilai-nilai tersebut tertanam dan menyatu dalam totalitas pikiran-tindakan.

Peserta didik SDN $054871 \mathrm{KW}$. Begumit, khususnya kelas 3 mendapat pendidikan karater salah satunya dari Fabel atau cerita yang menampilkan binatang sebagai tokoh cerita. Binatangbinatang tersebut dapat berpikir dan bertidak layaknya manusia, cerita fabel lebih digemari oleh peserta didik sehingga pesan moral lebih efesien untuk segera sampai atau bisa diterima anak-anak untuk kemudian dapat diimplementasikan di kehidupan sehari-hari

\section{Nilai Karakter di dalam fabel}

Adapun hasil dari pengamatan guru yang merupakan sumber penelitian, nilai-nilai karakter yang diajarkan dari fabel diantaranya adalah sikap jujur, bertanggung jawab dan rasa ingin menolong dan pesan moral lainnya. Tidak semua kisah diceritaka oleh guru secara mendetail, sebagian guru membiarkan siswa untuk memahami apa makna yang bisa diambil atau diteledani dari fabel atau kisah yang diceritakan. Para guru cenderung membuka ruang tanya jawab, membiarkan siswa mengeksplorasi sebuah cerita untuk kemudian dipahami dan diteladani.

\section{Hal-Hal Yang Mendukung Pembentukan Nilai Karakter}

Adapun hasil dari pengataman guru yang merupakan sumber penelitian, hal-hal yang dapat mendukung pembentukkan siswa diantaranya, buku-buku yang mengandung unsur fabel, komunikasi yang baik, implementasi yang nyata. siswa kelas 3 sekolah negeri dasar 091320 cenderung lebih menyukai pendekatan melalui kisah fabel, siswa menjadi aktif mendengarkan. Kemudian guru tidak lupa untuk mengimplementasikan bagaimana pesan moral tersebut berkerja, kadang guru membuka sesi tanya jawab atau meminta kesedian anak-anak untuk tampil kemudian menjadi tokoh dalam cerita.

\section{KESIMPULAN}

Berdasarkan observasi, wawancara dan dokumentasi di lapangan ditemukan bahwa:

Nilai-nilai karakter di dalam fabel yang dapat menjadi suri tauldan untuk siswa Sekolah Dasar Negeri 091320 diantaranya: sikap jujur, sikap tanggung jawab juga sikap rasa ingin menolong.

Pembentukkan karakter siswa SDN $054871 \mathrm{KW}$. Begumit melalui fabel pendidikan kewarganegaraan dilakukan dengan pendekatan buku-buku, komunikasi yang baik, serta implementasi yaitu dengan mengajak siswa berpartisipasi untuk tampil dan guru mengajak siswa untuk mengaplikasikan apa yang mereka dapat dari cerita-cerita fabel yang telah mereka pelajari bersama.

\section{DAFTAR PUSTAKA}

Abdullah Munir. 2010. Pendidikan Karakter; Membangun Karakter Anak Sejak Dari Rumah. Yogyakarta : Pustaka Insan Madani

Abrar, M. 2016. Learning from fabels: moral values in three selected english stories. Jurnal 
Dinamika Ilmu, 16 (1), 47-58

Agus Wibowo. 2013. Pendidikan Karakter Anak Usia Dini; Stratengi Membangun Karakter di Usia Emas. Yogyakarta : Pustaka Pelajar

Arifin \& Barnawi. 2012. Strategi \& Kebijakan Pembelajaran Pendidikan Karakter. Yogyakarta. Ar-Ruzz Media.

Jackson, M. M., \& Hesath, M. A. 2017. Preserving Guam's culture with culturally responsive children's stories. School Psychology International, 38(5), 458-472. doi:10.1177/0143034317719944

Kurniawan, Heru. 2013. Sastra Anak dalam kajian strukturalisme, sosiolohi, semiotika, hingga penlisan artikel kreatif. Yogyakarta: Graha Ilmu.

Lukens, Rebecca. 2013. A Critical Handbook of Children`s Literature. Newyork: longman.

Maksudin. 2013. Pendidikan Karakter Non Dikotomik. Yogyakarta : Pustaka Pelajar

Marzuki. 2015. Pendidikan Karakter Islam. Jakarta : Amzah

Maslamah. 2016. Nilai-nilai karakter dalam kurikulum Humanistik di FITIK IAIN Surakarta. At-Tarbawi: Jurnal Kajian Kependidikan Islam. h157

Muchlas Samani dan Hariyanto. 2012. Konsep dan Model Pendidikan Karakter. Bandung: PT Remaja Rosda Karya.

Raharjo. 2010. Pendidikan Krakter Sebagai Upaya Menciptakan Akhlak Mulia, Dalam Jurnal Pendidikan dan Kebudayaan, Jakarta: Balitbang Kementrian Pendidikan Nasional, Vol 16 No.3

Ramli, T. 2003. Pendidikan Moral dalam Keluarga. Grasindo; Jakarta

Saptono. 2011. Dimensi-Dimensi Pendidikan Karakter; Wawasan Strategi dan Langkah Praktis. Jakarta : Erlangga

Sjarkawi. 2006. Pembentukan Kepribadian Anak, Jakarta: PT Bumi Aksara, h. 1420

Thomas Lickona. 2013. Persoalan Karakter; Bagaimana Membantu Anak Mengembangkan Penilaian Yang Baik, Integritas dan Kebajikan Lainnya terj. Juma Abdu Wamaungo. Jakarta : Bumi Aksara

Tim Preschool Online. 2015. Serunya Dunia Anak Usia Dini. Jakarta : Panda Media

Wadi, Hairil. 2009. Integrasi Pendidikan Perdamaian dalam Pembelajaran IPS di SMP BOPKRI 3 Yogyakarta: UNY

Yono, S. 2014. Nilai edukasi dalam fabel Sentani. Jurnal Kandai, 10(1),102-11

Zainal Aqib. 2011. Pendidikan Karakter; Membangun Perilaku Positif Anak Bangsa. Bandung : Yrama Widya 